$78 \mid 2020$

Cours LANSAD à distance en situation de crise sanitaire

\title{
Flipped classrooms: Using Google Groups to facilitate in-class communication
}

Les classes inversées : l'utilisation de Google Groups pour faciliter la communication en cours

\section{Daniel Schug}

\section{OpenEdition}

\section{Journals}

Electronic version

URL: http://journals.openedition.org/asp/6882

DOI: $10.4000 /$ asp.6882

ISSN: 2108-6354

\section{Publisher}

Groupe d'étude et de recherche en anglais de spécialité

\section{Printed version}

Date of publication: 1 November 2020

Number of pages: 129-144

ISSN: 1246-8185

\section{Electronic reference}

Daniel Schug, "Flipped classrooms: Using Google Groups to facilitate in-class communication", ASp

[Online], 78 | 2020, Online since 01 November 2020, connection on 08 March 2021. URL: http://

journals.openedition.org/asp/6882 ; DOI: https://doi.org/10.4000/asp.6882

This text was automatically generated on 8 March 2021.

Tous droits réservés 


\title{
Flipped classrooms: Using Google Groups to facilitate in-class communication
}

\author{
Les classes inversées : l'utilisation de Google Groups pour faciliter la \\ communication en cours
}

Daniel Schug

\section{Foreword}

1 This report describes two mandatory one-semester ESP courses (English for International Relations) offered to second-and third-year undergraduates at the Institut National des Langues et Civilisations Orientales (INALCO) enrolled in the selective "international relations" track. The second-year course deals with topics related to jobs in international relations and the third-year course with topics related to recent issues in international relations and diplomacy. The common objective of both courses is to give students as many opportunities as possible to practise communication skills in class, and, at the same time, to make English use part of their everyday lives. This is achieved thanks to a Flipped Classroom (FC) model of instruction which is precisely where the novelty of the course lies. Although the report does not thoroughly detail course design and evaluation procedures, it could prove valuable to those willing to develop similar courses. The report also includes the results of a post-course survey which provides useful information to the course designer for future revisions (and an example for those who wish to evaluate similar courses) but does not make it possible to draw more general conclusions about the FC model as the response rate seems quite low (34\%, that is 24 participants out of 70 students) and therefore does not allow for generalizations.

2 The Flipped Classroom model is one of the possible implementations of what has been termed "blended learning", an educational approach which combines face-to-face sessions with online activities (Graham 2006). However, the FC model of instruction blends face-to-face and online activities in a very specific way as "activities traditionally conducted in the classroom (e.g., content presentation) become home activities, and activities normally constituting homework 
become classroom activities" (Akçayır \& Akçayır 2018: 334). This model of instruction entails opportunities as well as challenges, but the limited published literature to date merely points to best practices and to the numerous areas for future research. If videos, readings and quizzes are the most popular out-of-class activities in the FC model, whereas discussions, small group activities and problem solving activities are the most popular in-class activities (Akçayır \& Akçayır 2018), it should be noted that their popularity does not vouch for their efficiency in terms of second language acquisition (SLA) as more empirical studies are still needed in the field of SLA.

3 In the course described by D. Schug, students have to read authentic texts, view authentic videos and answer questions as out-of-class activities. These are made available online via a Google Group discussion board. The texts could also be used for grammar and vocabulary activities, although it is unclear what type of activities were given to students and when or how these were supposed to be completed.

Despite the fact that, as Cunningham (2017: 41) puts it in a rather provocative way, "there is nothing new about getting students to do some reading or view a video before class", these FC modalities call for three comments. First, the decision to use Google Groups as a discussion board is not self-evident, as other technological solutions could have been used with more functionalities and potentially fewer legal or ethical issues (one way of mitigating these issues being to use the Google Suite for Education).

In addition, if the stated objective of the courses is to ensure that they meet the needs of future international relations professionals, it is unclear what these professions are and what types of discourse and genres students will need to be familiar with. In this respect, D. Schug has paid special attention to authenticity, with videos, tasks and simulations adapted to target language use situations. Still, the activity based on the tweet by President Trump with the instruction "imagine you're the Danish Prime Minister" and to be completed in pairs cannot be considered as authentic, as neither "situational authenticity" nor "interactional authenticity" are achieved (Bachman 1990): first, to ensure situational authenticity, the characteristics of a task should match those of a target language use situation in the real world, which does not seem to be the case here as students are very unlikely to become the Danish Prime Minister and to have to reply to a tweet by Trump in that capacity; moreover, interactional authenticity of a task can only be ensured if it matches patterns of interaction similar to those found in the real world: again, students are very unlikely to have to exchange with a peer to come up with the appropriate response to a tweet by President Trump in the real world, and as reminded by Douglas (2001: 48), "mere emulation of a target situation (..) is not sufficient to guarantee communicative language use".

6 Thirdly, the courses described seem to combine online activities and face-to-face tasks, which is certainly a good way of making the most of the FC model as it is ideal for the implementation of more student-centered learning theories (project-based learning, collaborative learning, taskbased language teaching - TBLT, etc.). Still, the logical hierarchy of the course content and the different phases of the pedagogical cycle are unclear: the literature on CALL-based tasks points to an expanded pre-, during and post-task pedagogical cycle (Lai \& Li, 2011), which seems particularly relevant here even if the task itself is not necessarily CALL-based as it is completed in class. Some researchers even go as far as to write that the success of a task depends more on the pre-task and post-task activities than on the task itself (Salaberry 2001). Pre-task activities usually aim to prepare learners to complete the task in ways that foster acquisition through linguistic priming, information processing (from written or oral input), planning activities, observing models, consciousness-raising activities (Willis 1996, Narcy-Combes 2010), while post- 
task activities aim to follow up on task performance and build on the interactions generated during task completion through reflection on task performance and focus on forms. Willis' 1996 framework for Task-based Language Teaching (TBLT), which includes the three phases of the TBLT cycle, has been successfully implemented within a FC instructional model, both in the case of EFL courses (Cunningham 2017, Al-Naabi \& Nizwa 2020) and ESP courses (Duan 2020). For example, Cunningham (2017) suggests that students' out-of-class time should be spent on meaning-focused input (reading texts, viewing videos, listening to podcasts...) and form-focused learning (vocabulary, grammar or pronunciation activities), whereas their in-class time should be devoted to meaning-focused output and fluency development. In this respect, the nontransient nature of the teaching material developed or curated by the teacher to focus on form within a FC model makes it possible to individualize teaching and direct learners to a particular resource at the point of need (Cunningham 2017), especially in the post-task phase of the cycle. An appropriate technological environment therefore needs to be selected to ensure this material can be quickly made available to specific students (as opposed to the entire class), which tends point to more elaborate environments than discussion boards.

7 In a nutshell, two potential avenues to be explored in the future could be (1) to make the pedagogical cycle clearer and introduce post-task activities as well as remedial material for the students who need it and (2) to ensure that course content closely matches the needs of the future professions through more situationally and interactionally authentic tasks. The courses designed by D. Schug certainly have potential to increase student exposure to English outside the classroom, to allow students to work at their own pace and to free up some precious in-class time for more communicative tasks. In this respect, this teaching report is a valuable addition to the currently limited published contributions on flipping the ESP classroom. (Cédric Sarré, Sorbonne Université)

\section{Introduction}

Though not exactly a new phenomenon, blended learning programs have generated considerable buzz in the field of teaching. Indeed, numerous reports have been published describing the impact of various types of hybrid course setups, including flipped classrooms, international tele-collaboration activities, and language centers, all of which have the potential to give more autonomy to the learner and increase engagement (Desoutter \& Martin 2018; Terrier \& Maury 2015; Toogood \& Pemberton 2002; Webb et al. 2014). Language teachers in particular have been impacted by this push to incorporate innovative, technology-based strategies in the classroom (Basal 2015: 28). Still, Webb et al. (2014) and Alsowat (2016: 108) tell us that little research exists on these new teaching methods, especially in university language classrooms and institutions outside the United States. To add to the growing body of knowledge on blended learning, the present report describes a pilot project for a flipped classroom (FC) offered as a part of an English for International Relations (IR) course at Institut National des Langues et Civilisations Orientales (INALCO) in Paris, France.

9 To define the concept of FCs, Basal (2015: 29) explains that they generally have more passive activities, such as reading comprehension and listening to video lectures, offered to students via an online platform, before the lesson. In-class time, on the other hand, is often dedicated to interactive activities and project-based learning that allows students to put into practice what they learned from the autonomous activities. Afterwards, students have assignments that permit them to continue exploring the 
topic in other ways (Evseeva \& Solozhenko 2015: 207). Variations on this practice exist, as researchers note that not all lessons are suitable for this format and teachers may find it useful to experiment with different amounts of passive and active learning to do in the classroom (Hernández Nanclares \& Pérez Rodriguez 2015: 3). Still, the essence of these courses remains the same: students are asked to complete more passive activities outside the classroom and more interactive activities inside in the classroom.

Already, a number of studies have shown the benefits of an FC approach. From the teacher perspective, these courses have enormous potential for offering differentiated learning experiences for mixed-proficiency level classrooms and allowing students to learn at their own rhythm (Basal op. cit.: 29); lower-level students have the opportunity to review documents multiple times to ensure comprehension, while higher-level students can be given more challenging texts to work on. Moreover, Webb et al. (2014) found that teachers reported that FCs save time in lesson preparation and result in increased student collaboration. From the student perspective, Hernández Nanclares \& Pérez Rodriguez (2015: 10) found that students in a university-level, English-medium, FC course reported high levels of motivation and enjoyment; they felt they had more opportunities for communication and that the setup allowed them to pace themselves effectively. Alsowat (2016: 118) reported similar findings working with university-level language specialists; students were quite positive about the learning environment, noting high levels of engagement and satisfaction with the course design. Nazarenko (2015: 81) showed more conflicting results, but with still many learners reporting positive attitudes towards at least some aspects of the FC.

11 This report gives an example of one use of FCs in two courses of English for Specific Purposes (ESP) at a French university. It includes a description of the university and the courses, followed by results from a satisfaction survey distributed to students at the end of the one-semester course. Lastly, a conclusion section contains a reflection on how to improve the course design for future semesters. It is hoped that this report will present a useful strategy, particularly for instructors looking to take a first step towards implementing an FC in the university language course. Additionally, this report will also provide insight into student impressions about FCs.

\section{Context: Institut National des Langues et Civilisations Orientales}

This report describes an experience with two specialized English courses offered at Institut National des Langues et Civilisations Orientales (INALCO), a university located in Paris, France; one course was offered to second-year undergraduates while the other was offered to third-year undergraduates. As this university is somewhat unique in France, it deserves some additional explanation.

INALCO is an institution dedicated to training students for various foreign language careers. Students are therefore usually quite used to language learning and often enthusiastic about language courses.

In the first year of the Bachelor degree, students typically focus exclusively on the culture and language of their chosen specialty, without any English class. Starting in the second year, they have the opportunity to apply to one of several professionally 
oriented tracks to complement their language studies. This report deals specifically with the English courses offered to students in the international relations track.

In the international relations program, students are required to take a specialized English language course each semester of their second and third years, all of which are entitled "English for International Relations;" students are divided based on their academic year and not on their English proficiency levels. The courses are all offered in a face-to-face format with thirteen sessions of ninety minutes each. Class size is limited to thirty-five students per group, though for the two groups described here, enrollment is closer to twenty-five students.

On the whole, the English level of these students is quite advanced, with many starting the courses with a strong B2, based on the Common European Framework of Reference for Languages. A few exceptions exist in both groups, a couple of native speakers and a couple with a level closer to A2. Despite English not being a main focus for these students, they are often quite eager to improve. Aside from knowing the importance attached to English as a main language in international diplomacy, the students know they must achieve a C1 level to qualify for admission into INALCO's Master degree in International Relations. Moreover, having applied to a rather rigorous, selective professional track at INALCO, most of these students have detailed goals for future careers, many of which involve a good level of English. Together, these factors have resulted in a group of students that, on the whole, are quite motivated and positive about putting forth effort in order to learn English.

\section{Course design}

\subsection{Course title: English for International Relations}

As stated above, the English courses are a mandatory part of the two-year international relations track, built into the three-year Bachelor degree. The somewhat vague course title of "English for International Relations" allows the instructor significant liberty to adapt the courses to the needs and interests of the students, while still ensuring that it satisfies the specific needs of future international relations professionals. In very general terms, the major goal of this course was to provide students with an opportunity to incorporate English into their daily lives and to give them a significant amount of opportunities to practice communication skills during class time.

In designing this course, careful care was taken to incorporate Di Pardo Léon-Henri's (2015: 71) recommendations for creating authenticity in the language classroom; authentic documents, such as a video clips and news articles, were consistently selected to show students real uses for English, while realistic communicative tasks and simulations were proposed in-class to give students an opportunity to use the language in a context that would resemble something they could face in their future professional lives. This course thus features a number of the main elements frequently considered to be the hallmark of ESP (Far 2008; Khodi 2016: 13).

19 Concerning the course objectives, it was decided to give each course a thematic focus to guide learning. For the second-year students, the focus was "Jobs in International Relations;" the course presented various international organizations to give students ideas for jobs or internships in the future. Discussed topics included but were not limited to the North Atlantic Treaty Organization, the Arab League, and La 
Francophonie. The aim was to get learners to imagine the type of tasks they might have to complete in these institutions and equip them with the relevant speaking and writing skills.

The third-year course had a similar general spirit, though the thematic focus was "Recent Issues in International Relations and Diplomacy." The course presented students with various issues that arise that would require an international response. Discussed topics included but were not limited to Public Health with the Western African Ebola epidemic and Migration with the European Union's refugee crisis of 2015. The aim of the course was for learners to improve discussion and analysis skills by having them brainstorm possible strategies that governments could take for responding to these crises. Next, learners were also expected to acquire the necessary language to present the strategies professionally and diplomatically.

\subsection{Flipped classrooms via Google Groups}

For these two courses, I created a virtual classroom via the platform Google Groups. The main factor motivating the choice of this platform is its ease of use, as creating a classroom discussion board can be done in a matter of seconds. As you can see in Figure 1 below, one must simply enter a group name and a short description. Privacy settings ${ }^{1}$ can be modified at any time during or after group creation. The ease of use is evident even after the classroom is created. Teachers and, with authorization, students can post a discussion board entry with the click of a button and easily insert text, images and weblinks. Students also report finding this platform easy to use (see Table 1), likely because it is accessible on a smartphone or tablet.

Figure 1: Creation page for a Google Group

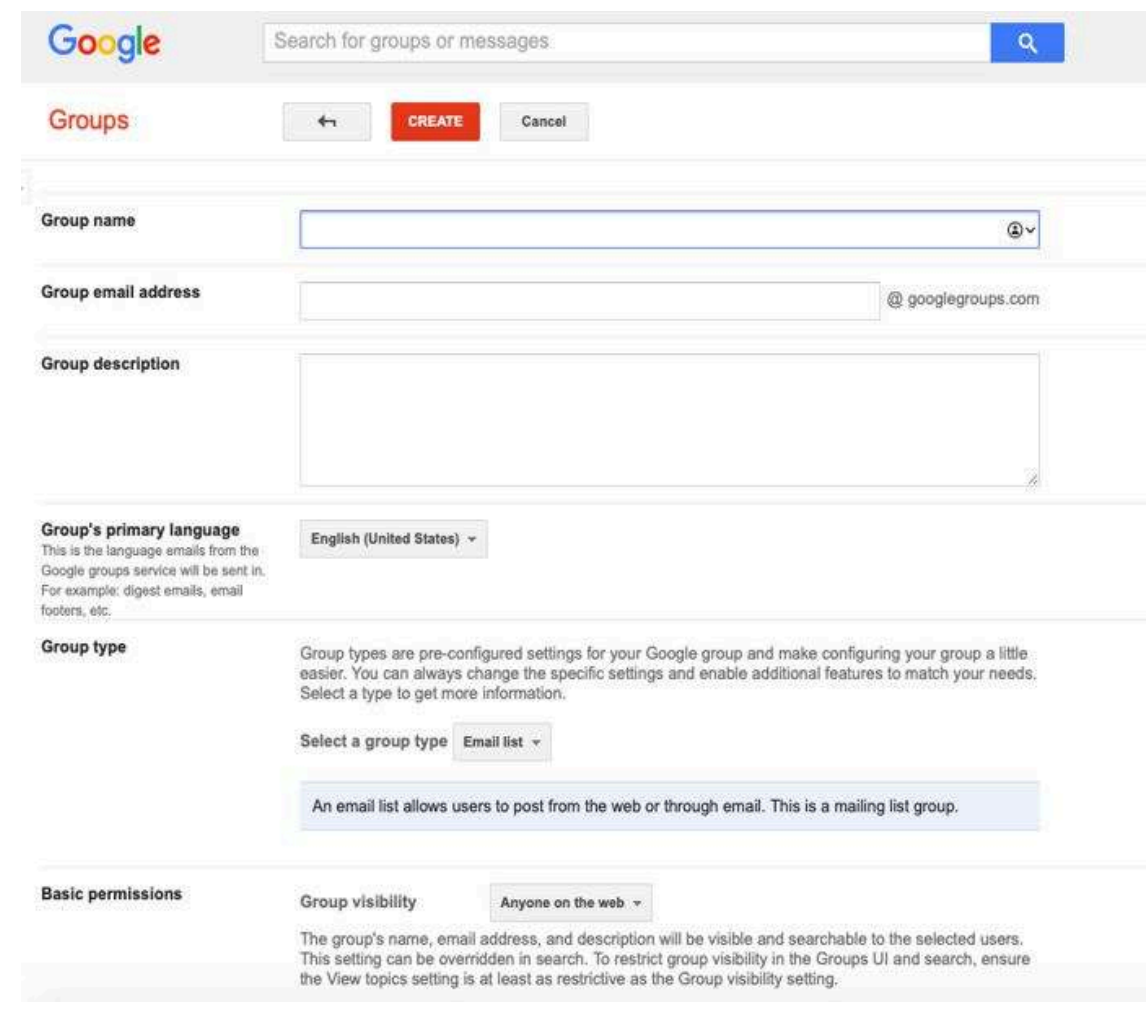



the corresponding lesson. I gave a short introduction, accompanied by two or three carefully selected documents that the students had to read, followed by a couple of guiding questions based on the issue described in the article, meant purely to stimulate discussion. Generally, the selected documents were newspaper reports of limited length, as students often had significant reading assignments in their other courses, but with sufficient advanced-level language so that they could also be used for grammar and vocabulary activities. They discussed recent topics of interest in international relations, identified after a preliminary analysis of student needs and interests at the beginning of the semester. Figure 2 below shows the teacher's post from the third-year course, on a week dedicated to Twitter Diplomacy and Technology in International Relations.

Figure 2: Teacher's post for a lesson on Twitter Diplomacy and Social Media in International Relations, third-year undergraduate course

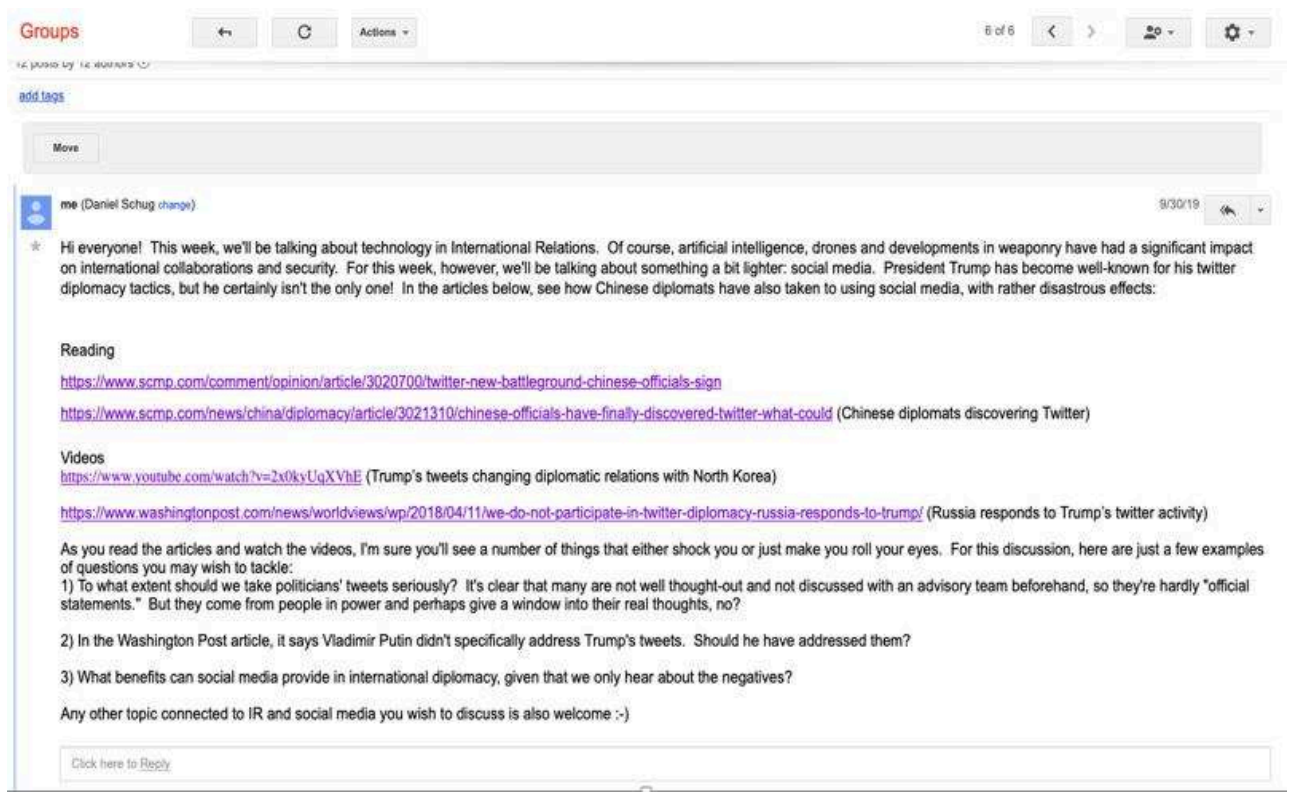

After, students were required to post a response within a week to the documents on the discussion board. This process was relatively simple and just required students to click "reply" underneath the teacher's post. These responses were visible to all members in the course; students were therefore allowed and encouraged to debate and discuss between themselves in preparation for the in-class lesson. This practice ensured that students had sufficient time to look at the materials at their own pace as well as critically analyze them for their discussion board participation. These discussion board posts were mandatory and constituted a large part of their final grade. As the owner of the group, I could choose to receive an email notification every time a student responded to a discussion board post, which proved to be very useful for keeping track of participation and evaluating the responses.

In class, lessons began with a review of any new vocabulary students may have encountered in the articles; this activity usually gave them some useful idioms, phrasal verbs, and terminology that could be used later on in the lesson. The rest of the lesson featured group oral and written activities based on the week's theme. In the case of this Twitter Diplomacy week, students were presented with the slide shown in figure 3. 


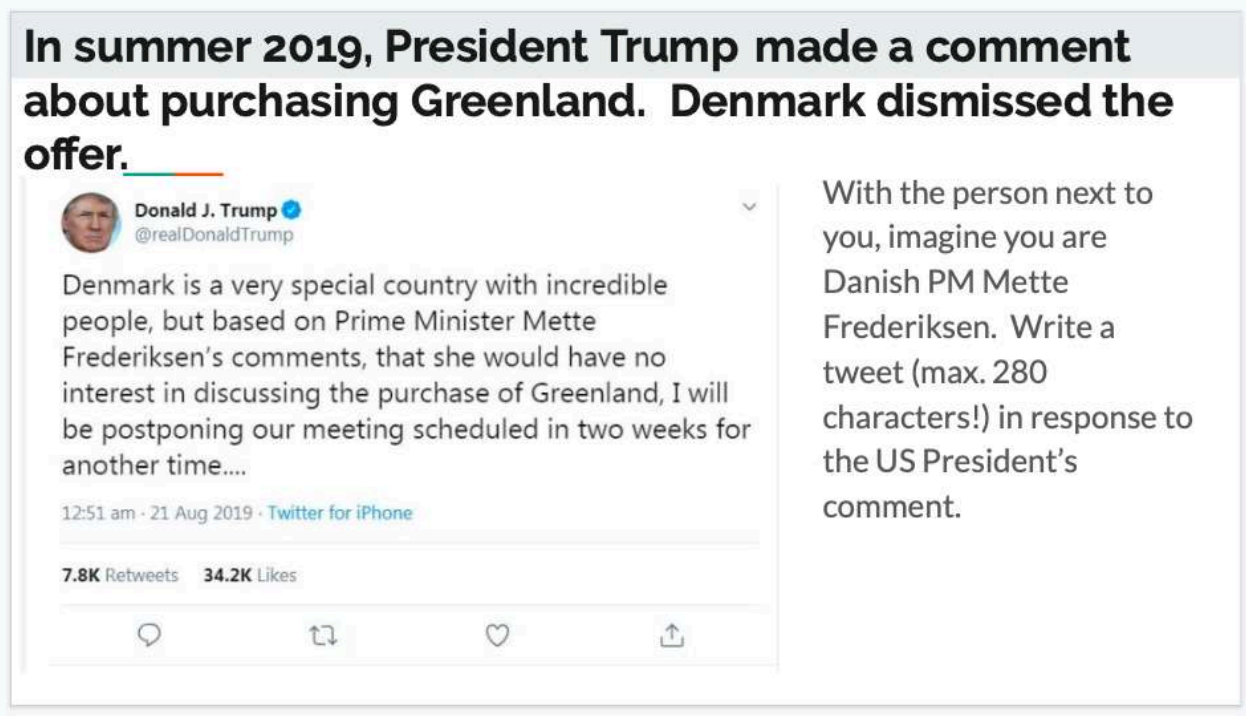

While this exercise served as trigger activity to practice responding diplomatically, the rest of the 90-minute lesson included small group discussions on the benefits and risks of the growing role of social media in international relations. As the teacher, I facilitated these conversations by circulating between groups to help generate ideas and guide discussions. After, the class came back together for a whole-class debate on the topic.

To delve further into the subject after class, students have the possibility to complete a written assignment. The last fifteen minutes of class time are dedicated to discussing how to structure the assignment, the content to include and useful expressions. The format of this assignment varies from week to week, but it might be professional writing (a CV, professional emails), academic writing (analytical essays, article summaries) or English test preparation for the French Foreign Ministry competitive exam (an essay about a recent topic of interest in foreign affairs). Students had to complete a minimum of two written assignments throughout the semester. For the topic of Twitter Diplomacy, students had to select one of the articles from the Google Group post and write a summary.

\section{Assessment of the flipped classroom program}

\subsection{Satisfaction questionnaire results}

As stated above, this FC experiment was simply a pilot project to test a new course design that incorporates more technology. The goals were to offer opportunities for students to use English in their daily lives (through participation in the virtual classroom) and to create situations for frequent practice with oral communication in realistic contexts. To determine whether these goals were met, a satisfaction questionnaire was distributed to students at the end of the semester. It asked them to rate 14 different elements in the class using a 5 -point Likert scale $(1=$ not at all in agreement, $5=$ very much in agreement). These questions were divided into points relating to the course design, presented in Table 1, and points relating to language 
practices, presented in Table 2. The second-year questionnaire received 13 responses, ${ }^{2}$ while the third-year received 11 responses. ${ }^{3}$

Table 1: Questions about the course design

\begin{tabular}{|l|l|l|}
\hline Question & $\begin{array}{l}\text { Second-year } \\
\text { undergraduate } \\
\text { (out of 5) }\end{array}$ & $\begin{array}{l}\text { Third-year } \\
\text { undergraduate } \\
\text { (out of 5) }\end{array}$ \\
\hline $\begin{array}{l}\text { I would've preferred to study the documents (articles/ } \\
\text { videos) in class with the help of the teacher* }\end{array}$ & 2.23 & 1.82 \\
\hline It's nice being able to work at my own pace in autonomy & 4.46 & 4.64 \\
\hline The Google Group platform is easy to use & 4 & 4.45 \\
\hline It's interesting to read the comments of my classmates & 3.62 & 3.82 \\
\hline $\begin{array}{l}\text { I speak more often in this class than I did in past English } \\
\text { courses }\end{array}$ & 3.38 & 4.27 \\
\hline $\begin{array}{l}\text { I read more often in this class than I did in past English } \\
\text { courses }\end{array}$ & 3.85 & 4.7 \\
\hline $\begin{array}{l}\text { The format of this course (videos/articles studied } \\
\text { autonomously, group activities in class) made the } \\
\text { learning experience pleasant }\end{array}$ & 4.38 & 4.6 \\
\hline I'm satisfied with the Google Group experience & 4.23 & 4.6 \\
\hline
\end{tabular}

*This question asks students to imagine another type of course setup. The low scores therefore indicate that they disagree with the other course setup, suggesting their preference for the setup used.

Table 2: Questions about language practices

\begin{tabular}{|l|l|l|}
\hline Question & $\begin{array}{l}\text { Second-year } \\
\text { undergraduate } \\
\text { (out of 5) }\end{array}$ & $\begin{array}{l}\text { Third-year } \\
\text { undergraduate } \\
\text { (out of 5) }\end{array}$ \\
\hline $\begin{array}{l}\text { When I study the Google Group documents before a } \\
\text { lesson, I feel more able to participate in class }\end{array}$ & 4 & 4 \\
\hline $\begin{array}{l}\text { Before writing a Google Group post, I take the time to } \\
\text { read all the corresponding documents }\end{array}$ & 4.69 & 4.09 \\
\hline $\begin{array}{l}\text { Thanks to this course, I am more comfortable } \\
\text { speaking }\end{array}$ & 3.85 & 4 \\
\hline $\begin{array}{l}\text { I take the time to look up new words and expressions } \\
\text { from the Google Group documents }\end{array}$ & 4.38 & 3.8 \\
\hline
\end{tabular}




\begin{tabular}{|l|l|l|}
\hline $\begin{array}{l}\text { When I write a comment, I take the time to make a } \\
\text { well-structured, error-free post }\end{array}$ & 4.46 & 4.6 \\
\hline My English improved in this course & 3.54 & 4.1 \\
\hline
\end{tabular}

I added a final open-ended question, asking students to offer any final comments on their experience in the course. Seven third-year and five second-year students responded, with largely positive answers; five of the third-years and three of the second-years simply noted that they really appreciated the interactive and communicative nature of the course, while one second-year said they appreciated the vocabulary activities. One second-year mentioned a specific activity that he/she liked and wished could have been repeated, while two third-years noted that they would have liked to have more opportunities to debate in class.

As the tables clearly show, in many cases, the third-year students were more positive about the FC experience, often by a large margin. The few exceptions in Table 2, however, show that perhaps the second-years dedicated more time to the virtual classroom than their third-year counterparts.

\subsection{Discussion and reflections for future practice}

The above report presents a first experience with a flipped classroom in an ESP course for undergraduate students in international relations. It describes a lesson and included responses from a student satisfaction questionnaire. Naturally, given these responses as well as my own observations, several modifications will be made moving forward.

31 First, it appears that second-year students were largely less satisfied than third-year students. Particularly striking is the fact that students reported only 3.54/5 for the statement "My English improved in this course." While these data might be hard to interpret given their overall positive responses to the Table 1 questions, research in ESP could explain part of this phenomenon; Ibba (1988) and Schug (2019: 282) found that students with lower language proficiency and students who are in the early stages of their majors may struggle with ESP courses, as they may lack both the specialized knowledge and the foreign language skills necessary to tackle complex ideas in their field. Schug (2019: 284) hypothizes also that, at a young age, university students may not have a very clear idea of what they will need the language for after their studies. To address these problems, a greater attention will be given to how students are currently using English so that the course can help them develop a more concrete idea of how English will be useful in their futures. Additionally, future versions of the course will seek to find a better balance between oral activities (simulations, role plays, debates) and language structures (terminology, grammar, typical formulations), so that students can more closely measure their own learning.

32 Also, it is quite striking that two students in the third-year course describe wanting to have more debates and opportunities to express their opinions. Indeed, small group work and simulations were the most commonly used oral activity, thereby avoiding the risk of a small group of students dominating in a whole-class debate or discussion. To address this point, already in the second semester, I have asked students to take 
greater responsibility in the management of the virtual classroom. Instead of personally posting documents and discussion questions, students are now in charge of selecting documents of interest to them and managing the online discussion board. This practice will, ideally, offer more autonomy to the students and allow them additional chances to express their opinions about topics of interest to them. Research indicates that this increased autonomy could encourage intrinsic learner motivation (Noels et al. 1999: 29).

Lastly, it is worth noting that using a Google tool did generate some controversy, generally stemming from students who had concerns about privacy and the security of their data. Only a few students expressed these concerns and we were able to find solutions that were satisfactory to all involved. I explained to students, for example, that they did not have to create a Google account as it is not required to be part of a Google Group and receive group information. Also, while students would generally participate in the group discussion board directly on the group's webpage, students who were uncomfortable with this practice were able to receive notifications of a post and offer their own responses all via email. Together, these two practices ensured that all students could be included and participate in a way they found acceptable that did not require significant accommodation.

Despite these issues, the results from this first attempt at a FC setup are promising as the overall course goals were partially met. Third-year students largely reported that they spoke and read more in this course than they did in past English courses and that they took care in constructing well thought-out discussion board posts. Second-year students largely indicated that they spent a lot of time analyzing the Google Group documents and formulating good responses. Lastly, perhaps most importantly, students responded positively regarding overall course satisfaction and an appreciation for being able to work at their own pace. Taken together, these results along with responses to the open-ended question, suggest that students find that the FC course does allow them more opportunities to communicate in class and that, in some cases, they gain greater exposure to English. Moving forward, these results have given some clear directions for course improvement.

\section{BIBLIOGRAPHY}

AKÇAYIR, Gokce. \& Murat AKÇAYIR, M. 2018. “The flipped classroom: A review of its advantages and challenges". Computers \& Education 126 334-345.

AL-NAABI, Ishaq Salim. 2020. "Is it Worth Flipping? The impact of flipped classroom on EFL students' grammar”. English Language Teaching 13/6 144-155.

ALSOWAT, Hamad. 2016. “An EFL flipped classroom teaching model: Effects on English language higher-order thinking skills, student engagement and satisfaction". Journal of Education and Practice 7/9, 108-121. 
BASAL, Ahmet. 2015. "The implementation of a flipped classroom in foreign language teaching”. Turkish Online Journal of Distance Education 16/4, 28-37.

CUNNINGHAM, Una. 2017. “Flipping the language classroom”. The New Zealand Language Teacher 43 41-50.

DESOUTTER, Cécil \& Justine MARTIN. 2018. “Engagement et degré de satisfaction d'étudiants de FLE dans une activité d'écriture télécollaborative italo-espagnole". Revue Internationale de pédagogie de l'enseignement supérieur 34/2. Retrieved from <https://journals.openedition.org/ripes/ 1386\#quotation>.

DI PARDO LÉON-HENRI, Dana. 2015. “L'apprentissage de l'anglais de spécialité : de l'authenticité au développement d'une identité authentique". The Journal of Languages for Specific Purposes 2, 61-74. DUAN, wei. 2020. "On the "flipped classroom"teaching model trough task-based language teaching from the perspective of constructivist learning theory: A case of Hotel English Reform in Yinxing hospitality management college of CUIT". In: SUN, Y., L. LI \& H. CAI (Eds), Asian Research on English for Specific Purposes. Singapore: Springer, 209-227.

FAR, Mohammad Mohseni. 2008. “On the relationship between ESP \& EGP: A general perspective”. ESP 1/7. Retrieved from h<ttp://www.esp-world.info/Articles_17/issue_17.htm>.

EVSEEVA, Arina \& Anton SOLOZHENKo. 2015. “Use of flipped classroom technology in language learning”. Procedia - Social and Behavioral Sciences 206, 205-209.

GRAHAM, Charles R. 2006. "Blended learning systems: Definition, current trends and future directions. In BONK, C.J. \& C.R. GRAHAM, The Handbook of Blended Learning: Global Perspectives, Local Designs. San Francisco, CA: Pfeiffer, 3-21.

HERNÁNDEZ NANCLARES, Núria \& Mónica PÉREZ RODRÍGUEZ. 2015. “Students' satisfaction with a blended instructional design: The potential of a 'flipped classroom' in higher education". Journal of Interactive Media in Higher Education 1/4,1-12.

IBBA, Maria. 1988. "L'inglese della medicina. In Congresso su Le lingue di specializzazione e il loro insegnamento nella scuola secondaria e nell'università". Il *linguaggio delle scienze e il suo insegnamento. In Centro Di Linguistica Dell'università Cattolica. Atti del Congresso su Le lingue di specializzazione e il loro insegnamento nella scuola secondaria e nell'università Brescia, 2--4 aprile 1987. Brescia, Italy: Editrice La Scuola, 169-185.

KHODI, Ali. 2016. "From an appraisal of Iranian ESP courses to curriculum development". Research in English Language Pedagogy 3/2, 13-20.

LAI, Chun \& Guofang LI. 2011. "Technology and task-based language teaching: A critical review". CALICO Journal 28/2 498-521.

NARCY-COMBES, Jean.-Paul. 2010. "Pedagogic consequences: a task-based approach to distance second language learning”. In BERTIN, J.C., P. GRAVÉ, \& J.-P. NARCY-COMBES (Eds.), Second-Language Distance Learning and Teaching: Theoretical Perspectives and Didactic Ergonomics. Hershey, PA: IGI Global, 223-245.

NAZARENKO, Alla. 2015. "Blended learning vs traditional learning: What works? (A case study research)”. Procedia - Social and Behavioral Sciences 200, 77-82.

NOELS, Kimberly, Richard CLÉMENT \& Luc PELLETIER. 1999." Perceptions of teachers' communicative style and students' intrinsic and extrinsic motivation". The Modern Language Journal 83/1, 23-34. 
SALABERRY, M. Rafael. 2001. “The use of technology for second language learning and teaching: A retrospective”. Modern Language Journal 85 39-56.

SCHUG, Daniel. 2019. "English courses across disciplines: A question of motivation". Unpublished doctoral thesis. Université de Paris VIII Vincennes-Saint-Denis, France and Università Ca' Foscari Venezia, Italy.

TERRIER, Linda \& Cristelle MAURY. 2015. "De la gestion des masses à une offre de formation individualisée en anglais-LANSAD : Tensions et structuration”. Recherche et Pratiques Pédagogiques en Langues de Spécialité 34/1, 67-89.

TOOGOOD, Sarah \& Richard PEMBERTON. 2002. "Integrating self-access language learning into the curriculum: A case study". In BENSON, P. \& S. TOOGOOD (Eds.), Challenges to Research and Practice. Learner Autonomy. Dublin, Ireland: Authentik Language Learning Resources Ltd, 85-109.

WEBB, Marie, Evelyn DOMAN \& Kerry PUSSEY. 2014. "Flipping a Chinese university EFL course: What students and teachers think of the model". The Journal of Asia TEFL 11/4, 53-84.

WILLIS, Jane. 1996. A Framework for Task-Based Learning. Harlow, UK: Longman.

\section{NOTES}

1. When creating the group, some basic privacy options are offered, such as limiting who can post in the group, controlling who can join the group, who can view the group's content and who can post in the group. In the case of my classes, the group was private and accessible only to members added by me. All members were enrolled students and had the right to view material and post in the group.

2. Link to the second-year responses: <https://docs.google.com/spreadsheets/d/ 1zBKGc40MVKc5-04WCoNXsQn4lw9mlnxU6PIXz80TUVI/edit?usp=sharing>

3. Link to the third-year responses: <https://docs.google.com/spreadsheets/d/1itzgmACy4CCssBmlOxPc_QVURwHEPMtw1_FnJ4_54A/edit?usp=sharing>

\section{INDEX}

Mots-clés: anglais de spécialité, apprentissage mixte, classe inversée, Google Groups, relations internationales

Keywords: blended learning, English for Specific Purposes, flipped classroom, Google Groups, international relations

\section{AUTHOR}

\section{DANIEL SCHUG}

Daniel Schug holds a PhD in English and Foreign Language Teaching granted jointly by Université Paris 8 and Università Ca' Foscari Venezia. He is currently a maître de conférences at Université 
Paris Nanterre where he teaches specialized English courses for students majoring in other disciplines. As a member of the GrEG research group, he also conducts research on the psychological aspects of language learning and on the use of technology in language courses. dpschug@gmail.com 